\title{
Synthesis and evaluation of composite Ti0 2 @ Zno quantum dots on hybrid nanostructure perovskite solar cell
}

Negin Pezhooli

Iran University of Science and Technology

Ali Maleki ( $\square$ maleki@iust.ac.ir)

Iran University of Science and Technology

Farzam Hasti

Gorgan University of Agricultural Sciences and Natural Resources

Jamal Rahimi

Iran University of Science and Technology

Research Article

Keywords: Solar cell, Nanotechnology, Environment, Perovskite, Clean Energy.

Posted Date: March 3rd, 2022

DOI: https://doi.org/10.21203/rs.3.rs-1376793/v1

License: (a) (i) This work is licensed under a Creative Commons Attribution 4.0 International License.

Read Full License 


\section{Abstract}

This research is an interdisciplinary study aimed at helping the environment and producing clean energy. Therefore, one of the goals of this research towards the field of nanotechnology is the application of nanotechnology in the preparation of solar cells and the provision of optimal and efficient cells. Perovskite solar cells are of particular importance because of the high efficiencies that they have achieved in recent years. The use of quantum dots has also played an important role in the efficiency of these cells and their efficiency. The $\mathrm{TiO}_{2} @ \mathrm{ZnO}$ nanocomposite was selected and synthesized for this study. The application of this nanocomposite with different ratios of $\mathrm{TiO}_{2}$ and $\mathrm{ZnO}$ quantum dots was investigated and their efficiency was determined. Although the efficiency of the fabricated cell was reported to be about $5 \%$ in a solar cell made of $\mathrm{TiO}_{2} @ \mathrm{ZnO}$ composite, the efficiency can be increased by optimizing conditions such as the optimal location for these cells or by compositing with other materials.

\section{Introduction}

With the widespread use of fossil fuels around the world, energy shortages have become a serious challenge. To solve these problems, the use of renewable energy such as solar energy has been studied (Sun et al., 2021; Xing et al., 2013; Stranks et al., 2013). Sun is a huge source of energy and solar energy is the unique renewable, convenient, and main source of all the available energy on Earth. Many efforts have been made today to exploit this great energy source. Solar cells are one way to use this energy. Nowadays, organometallic perovskite solar cells have become a powerful alternative to popular commercialized silicon solar cells due to their easy synthesis, inexpensive components, and low fabrication costs (Im et al., 2011; Noh et al., 2013).

In the past few decades, research activities on nanomaterials have grown rapidly since materials in nanosize exhibit completely different properties as compared to their bulk properties (Rajib et al., 2021). Quantum dots (QDs) grabbed lots of attention in recent years because of their amazing characteristics in optics. The energy gap of QDs depends on their sizes and synthesis methods. (Weimin et al., 2016; M.Sajimol et al., 2012; Y.H. Tong et al., 2004; D. Sun et al., 2008). Quantum dots (QDs) have the advantage of tunable bandgap as a result of size variation as well as the formation of intermediate bands (Jasim, 2018).

Since the application of perovskite light absorber with the formula $\left(\mathrm{CH}_{3} \mathrm{NH}_{3} \mathrm{Pbl}_{3}\right)$ in the construction of solid-state solar cells in 2012, a lot of research work has been done in the field of perovskite solar cells, so that in a few years the efficiency of these cells to increase by $25.5 \%$ (Shalan et al., 2021; Shalan et al., 2021; Khan et al., 2020). Studies show that the research into improving the efficiency of solar cells includes introducing new compounds or new methods of preparing these cells or improving existing compounds and methods. Since the solid-state perovskite cell consists of several layers consisting of compact $\mathrm{TiO}_{2}$, mesoporous $\mathrm{TiO}_{2}$, perovskite light-absorbing layer, a hole-transport layer, and electrode (Au) (Pourradi et al., 2019), these studies can be performed on any part of the cell (Lee et al., 2012). Nanotechnology and nanoscale materials can be introduced in some of these layers to increase the 
efficiency of the solar cell. To review some of the research on the application of nanotechnology in the field of perovskite solar cells, the following can be referred to: A: Research cavity barrier layer (McDonal et al., 2019), B: Mesoporous $\mathrm{TiO}_{2}$ research layer (Dar et al., 2014; Sun et al., 2015), C: Perovskite lightabsorbing layer of research (Chueh et al., 2015; Hwang et al., 2015), d: study hole transfer layer (Malinkiewicz et al., 2014; Docampo et al., 2014).

Increase energy efficiency, can lead to the optimization of perovskite solar cell construction conditions, which can be used in the field of nanotechnology. Also, locating and optimizing the establishment of solar cell farms is another way to increase energy efficiency.

This research is an interdisciplinary study that aims to help the environment and produce clean energy, so one of the objectives of this research in the field of nanotechnology and the environment is the application of nanotechnology in the preparation of solar cells and the presentation of optimal cells and it is productive. In this regard, as an example, we will synthesize the $\mathrm{TiO}_{2}$ @ $\mathrm{ZnO}$ composite and study the electron donor properties, improve the gap band and material absorption coefficient, and its effect on the efficiency and flow-potential diagram in the perovskite solar cell. This article has been prepared in two parts. The second part of this research has discussed suitable locations for perovskite solar cells in Kurdistan province located in western Iran (Hasti et al 2022).

\subsection{Background on nanocomposite and perovskite solar cell}

One of the goals of this research in the field of nanotechnology is to provide optimal and efficient solar cells. As an example, we will synthesize the $\mathrm{TiO}_{2} @ \mathrm{ZnO}$ composite and study its electron-giving properties in the perovskite solar cell. To do this, we used the quantum dots of $\mathrm{TiO}_{2}$ and $\mathrm{ZnO}$. Quantum dots are semiconductor crystals in the nanoscale $(1-10 \mathrm{~nm})$. Semiconductors are materials whose electrical conductivity is the interface between the electrical conductivity of conductive and non-conductive materials. Titanium dioxide due to its many properties including high refractive index, Lewis acid property, semiconductor and as an absorber of ultraviolet and visible light in photocatalytic applications and cheapness, high chemical stability, and non-toxic nature among other important metal oxides has special importance. Zinc oxide is also an important semiconductor with a band gap of 3.37 electron volts and high excitation energy of $60 \mathrm{mV}$ at room temperature. In recent years, zinc oxide has attracted much attention mainly due to its unique optical, electronic, and piezoelectric properties, as well as its potential application in solar cells, blue light emitting diodes, sensors, and dimmers. This material can be used in optical instruments in ultraviolet and visible regions. At the nanoscale, it is also a highly transparent semiconductor with strong luminescence at room temperature, making it an ideal choice for a variety of sensors, laser diodes, displays, and transparent electrodes. Zinc oxide is biocompatible and safe and can be used in medicine and solar cells. Composite refers to solids that have more than one component used in their structure. A composite material is a physical, not a chemical, mixture on a macroscopic scale of two or more different materials. These materials retain their physical and chemical properties, but in general, the mixture has better properties than each of its components (Ajayan et al., 2003). The bonds that small material makes with its surrounding phases are much stronger than on larger scales. 
Accordingly, a new branch of composites called nanocomposites has been introduced and developed. The nanocomposite is a composite material in which at least one of its constituent phases has nano dimensions (between 1 and 100 nanometers) (Luo \& Daniel, 2003). Nanocomposites have a wider range of applications compared to other composites due to their more desirable physical, mechanical, and chemical properties (Theng, 2012). In general, there are three generations of solar cells, of which the perovskite solar cell is a third generation solar cell. The general formula for perovskite compounds is $A B X_{3}$, in which (A) can be a mono-valent organic or inorganic cation surrounded by twelve anions. (B) Is a divalent cation of the group of four principal bonds with six anions that forms an octagon. The combination of these octahedrons has created cavities that are occupied by a cation of organic or inorganic capacity and a perovskite structure. And X represents halogen atoms. The total oxidation number of cations and anions is equal to three, which has contributed to the charge balance and stability of the crystal structure (Prakash Singh \& Nagarjuna, 2014). Synthesis of the $\mathrm{MAPbl}_{3} \mathrm{compound}$ performed by Weber and proposed a cubic structure for this compound and showed that the methyl ammonium group or $\mathrm{C}_{3} \mathrm{v}$ symmetry must be twisted to provide the necessary symmetry to form the facet octagon. As mentioned, in these compounds, phase change occurs with temperature change, and the combination, $\mathrm{MAPb}_{3}$, also changes phase with temperature change from cubic to tetragonal. In addition to sensitivity to temperature and pressure, perovskite compounds are highly sensitive to moisture, which should be taken into account when preparing these compounds, so that they are not exposed to moisture because water enters the crystal structure of these compounds. These compounds change from black with the formula $\mathrm{MAPbl}_{3}$ to yellow with the formula $\mathrm{MA}_{4} \mathrm{Pbl}_{6} \cdot 2 \mathrm{H}_{2} \mathrm{O}$ (Baikie et al., 2013). The results of the research indicate the sensitivity of these compounds to temperature, pressure, and humidity, and this evidence suggests that when preparing these compounds, temperature and humidity control should be considered to obtain a perovskite compound with the appropriate phase.

\section{Material And Method}

\section{2-1 Laboratory equipment and chemicals}

\section{Laboratory equipment}

The products were identified using infrared spectra by Shimadzu infrared spectrometers in the form of potassium bromide tablets. FE-SEM (Field Emission Scanning Electron Microscope) images were taken using the MIRA3 TESCAN device.

\section{Chemicals}

All materials include potassium hydroxide, zinc acetate, titanium isopropoxide, tetra isopropyl orthotitanate, high purity iodide, dry ethanol solutions, ethyl acetate, hydrochloric acid, methylamino acid, hydrochloric acid, and hydrochloric acid Supplied by Merck and Aldrich companies.

\section{2-2 Synthesis of materials}




\section{Synthesis of $\mathrm{ZnO}$ quantum dots}

They were first agitated by a magnetic stirrer in various containers of $\mathrm{KOH}$ in ethanol and $\mathrm{Zn}(\mathrm{CH} 3 \mathrm{COO})_{2}$ $\cdot 2 \mathrm{H} 2 \mathrm{O}$ in ethanol, and then ultrasonic at room temperature for one hour. Then drop by drop of a container containing $\mathrm{KOH}$ solution was added to the container containing the solution of acetate for two hours by magnetic stirring at room temperature.

Ethyl acetate was then added to obtain $\mathrm{ZnO}$ quantum dot precipitate. Finally, the resulting solution was washed with additional ethanol and placed in an oven at $70^{\circ} \mathrm{C}$ to dry (Geng et al., 2017).

\section{Synthesis of $\mathrm{TiO}_{2}$ quantum dots}

Titanium isopropoxide $\left(\mathrm{C}_{12} \mathrm{H}_{28} \mathrm{O}_{4} \mathrm{Ti}\right)$ was added to ethanol and stirred for 20 minutes at room temperature to form a precursor solution with a magnetic stirrer. Then aqueous ethanol solution (ethanol/water 1: 1) was added drop by drop to the precursor solution under ultrasound and then the solution was stirred with a magnetic stirrer for one hour at room temperature. Finally, the whole solution was placed in an autoclave at $150^{\circ} \mathrm{C}$ for 12 hours.

The resulting precipitate was cooled to room temperature and then centrifuged. The solution was then washed with water and ethanol and placed overnight at $50^{\circ} \mathrm{C}$ to dry. The precipitate was then collected and calcined at $45^{\circ} \mathrm{C}$ for 2 hours (Kaur et al., 2015).

\section{Synthesis of $\mathrm{CH}_{3} \mathrm{NH}_{3}$ I}

The methylamine was stirred with the hydriodic acid in a $250 \mathrm{ml}$ round bottom flask at $0^{\circ} \mathrm{C}$ (ice bath) for two hours. The solution was then rotated at $50^{\circ} \mathrm{C}$ to remove solvents, which precipitated. The crude white to slightly yellow $\mathrm{CH}_{3} \mathrm{NH}_{3}$ l product was washed three times with diethyl ether to give a white powder. After filtration, the solid was collected and dried in a vacuum oven at $60^{\circ} \mathrm{C}$ for 24 hours. The resulting white solid was used without purification (Chen et al., 2015).

\section{Synthesis of $\mathrm{CH}_{3} \mathrm{NH}_{3} \mathrm{Pbl}_{3}$ nanoparticles}

To obtain $\mathrm{CH} 3 \mathrm{NH} 3 \mathrm{Pbl} 3$ nanoparticles, two compounds, $\mathrm{CH}_{3} \mathrm{NH}_{3}$ and $\mathrm{Pbl}_{2}$, were each separately dissolved in isopropanol. The manufacturing steps are as follows: First, $0.25 \mathrm{M} \mathrm{CH}_{3} \mathrm{NH}_{3}$ I solution was sonicated for 30 seconds. Then $0.25 \mathrm{M} \mathrm{Pbl}_{2}$ solution was added dropwise to $\mathrm{CH}_{3} \mathrm{NH}_{3}$ I solution for 30 minutes. A color change from yellow to dark brown was observed after the addition of two precursors and their mixing, indicating the occurrence of a chemical reaction. In this experiment, the purity of $\mathrm{Pbl}_{2}$ is very important because if it is not pure enough, a good result will not be obtained (Bhooshan Kumar et al., 2016).

\section{Composite synthesis of $\mathrm{TiO}_{2} @ \mathrm{ZnO}$ quantum dots}




\section{2-3 Identification analysis and determination of efficiency}

In the synthesis of this composite, different amounts of $\mathrm{TiO}_{2}$ with ratios of 1:1, 2:1, and 1:2 to the quantum dots of $\mathrm{ZnO}$ were used. In a 1:1 ratio in separate containers, $\mathrm{KOH}$ in ethanol and zinc acetate along with quantum dots of $\mathrm{TiO}_{2}$ in ethanol was first stirred with a glass stirrer and sonicated at room temperature for one hour. Then drop by drop of $\mathrm{KOH}$-containing solution was added to the zinccontaining solution for two hours by magnetic stirring at room temperature, and then ethyl acetate was added to precipitate $\mathrm{ZnO}$ quantum dots. The resulting solution was washed with excess ethanol and water and placed at $70^{\circ} \mathrm{C}$ to dry. $\mathrm{A}$ 2:1 ratio and a 1:2 ratio of $\mathrm{TiO}_{2}$ and $\mathrm{ZnO}$ were used in the same manner as previously. Finally, the perovskite solar cell was fabricated by spin coating deposition and immersion (Liang et al., 2015; Hwang et al., 2015; Barrows et al., 2014).

\section{Investigation of the infrared (FT-IR) spectra of $\mathrm{TiO}_{2}$ and $\mathrm{ZnO}$ quantum dots and their composites:}

Figure 1 shows the infrared spectrum of $\mathrm{TiO}_{2}$ and $\mathrm{ZnO}$ quantum dots and their composite. Infrared spectrum related to $\mathrm{ZnO}$ quantum dots, peak $447 \mathrm{~cm}^{-1}$ related to $\mathrm{Zn}-0$ vibration, peak $705 \mathrm{~cm}^{-1}$ related to $\mathrm{Zn}-\mathrm{OH}$, peak $1352 \mathrm{~cm}^{-1}$ related to $\mathrm{C}=\mathrm{O}$ bond Zinc acetate, spectrum $1487 \mathrm{~cm}^{-1}$ Related to the $\mathrm{C}=\mathrm{C}$ bond of zinc acetate, the peak of $1577 \mathrm{~cm}^{-1}$ corresponds to the stretching vibration of $\mathrm{C}-\mathrm{H}$ zinc acetate and the peak of $3294 \mathrm{~cm}^{-1}$ corresponds to the $\mathrm{O}-\mathrm{H}$ bond.

In the case of the infrared spectrum of the wide peak $\mathrm{TiO}_{2}$ quantum dots observed at 3000 to $3400 \mathrm{~cm}^{-1}$, it is related to the stretching vibration of the hydroxyl group $(-\mathrm{OH})$, which represents water as moisture. The peak observed in $1627 \mathrm{~cm}^{-1}$ is related to the stretching $\mathrm{C}=0$ of titanium carboxylate, which is due to the presence of titanium isopropoxide and ethanol as a precursor. The weak peak observed in $1047 \mathrm{~cm}^{-1}$ belongs to the Ti-O-C group and the peak observed in $474 \mathrm{~cm}^{-1}$ and $800 \mathrm{~cm}^{-1}$ is due to the presence of stretching $\mathrm{Ti}-\mathrm{O}$ in $\mathrm{TiO}_{2}$.

\section{Investigation of $\mathrm{FE}-\mathrm{SEM}$ images of $\mathrm{TiO}_{2}$ and $\mathrm{ZnO}$ quantum dots}

FE-SEM images show $\mathrm{TiO}_{2}$ and $\mathrm{ZnO}$ quantum dots, particle size distribution, and particle morphology. As shown in Fig. $2, \mathrm{TiO}_{2}$ quantum dots have a spherical morphology and have a particle size distribution between 6-8 $\mathrm{nm}$. The particles are slightly agglomerated, resulting from the agnomerization of small quantum dots. In the case of $\mathrm{ZnO}$ quantum dots, it is also observed that the particles have a spherical morphology and have a particle size distribution between 5-9 $\mathrm{nm}$.

\section{Investigation of TEM images of $\mathrm{TiO}_{2}$ and $\mathrm{ZnO}$ quantum dots and $\mathrm{TiO}_{2} @ \mathrm{ZnO}$ composite}

Figure 3 shows the TEM images of TiO2 and $\mathrm{ZnO}$ quantum dots and their composite. The average particle size of TiO2 quantum dots is about $7 \mathrm{~nm}$. This indicates that different sizes of irregular shapes of $\mathrm{TiO} 2$ quantum dots have grown in large quantities in the agnomere state and the average of $\mathrm{ZnO}$ quantum dots is 6 nanometers. 


\section{XRD characterization of $\mathrm{TiO}_{2}$ and $\mathrm{ZnO}$ quantum dots and $\mathrm{TiO}_{2} @ \mathrm{ZnO}$ composite}

As shown in Fig. 4 , diffraction peaks at $25.3^{\circ}, 38.0^{\circ}, 48.1^{\circ}, 54.2^{\circ}, 55.1^{\circ}, 62.8^{\circ}, 68.9^{\circ}, 70.4^{\circ}$ and $75.3^{\circ}(2 \theta)$ marked in XRD pattern are well indexed with crystal planes of anatase (101), (004), (200), (105), (211), (204), (116), (220) and (107) indices of $\mathrm{TiO}_{2}$, respectively. This observation confirms the existence of anatase phase which matches well with the reference card (JCPDS-\#21-1272). (Amandeep Kaur et al., 2015; P. Kundu et al., 2014; S. Sood et al., 2014)

Diffraction peaks at $31.68^{\circ}, 34.35^{\circ}, 36.09^{\circ}, 47.36^{\circ}, 56.48^{\circ}, 62.70^{\circ}, 66.23^{\circ}, 67.87^{\circ}, 68.99^{\circ}$ and $76.77^{\circ}$ marked in XRD pattern with crystallographic pages (1 $\left.\begin{array}{lll}1 & 0\end{array}\right),\left(\begin{array}{lll}0 & 0 & 2\end{array}\right),\left(\begin{array}{lll}1 & 0 & 1\end{array}\right),\left(\begin{array}{lll}1 & 0 & 2\end{array}\right),\left(\begin{array}{lll}1 & 1 & 0\end{array}\right),\left(\begin{array}{lll}1 & 0 & 3\end{array}\right),\left(\begin{array}{lll}1 & 1 & 2\end{array}\right)$ and $\left(\begin{array}{lll}2 & 0 & 1\end{array}\right)$ are well indexed vortex phase of $\mathrm{ZnO}$ respectively which is well compatible with the reference card (JCPDS No 36-1451) (Weimin Yang et al., 2016).

\section{Investigation of I-V diagram of Perovskite solar cell in 2:1 ratio of $\mathrm{TiO}_{2} @ \mathrm{ZnO}$ composite}

Current-voltage analysis is the first and most basic analysis of a solar cell. In this analysis, cell efficiency as well as open circuit voltage, short circuit current and cell filling factor are determined. Three perovskite solar cells for each ratio were fabricated and three tests were taken from each to obtain the best performance. The best yield for 2:1 $\mathrm{TiO}_{2}: \mathrm{ZnO}$ ratio was $5.21 \%$, for $1: 1 \mathrm{TiO}_{2}: \mathrm{ZnO}$ was 2.3 and for 2:1 $\mathrm{ZnO} @ \mathrm{TiO}_{2}$ was 3.7. Results of Fig. 5 were obtained from the calculation of current and voltage according to the calculations performed.

\section{Discussion And Conclusion}

Due to the growing energy consumption, limited current energy production resources, increased productivity of solar-powered equipment, the simplicity of installation, commissioning and use of equipment and the low cost of equipment with solar energy the use of solar energy is becoming more widespread day by day. Perovskite solar cells are of particular importance because of the high efficiencies they have achieved in recent years. The use of quantum dots has also played an important role in the efficiency of these cells and their efficiency. The $\mathrm{TiO}_{2} @ \mathrm{ZnO}$ composite was synthesized for the first time and the application of this composite with different ratios of $\mathrm{TiO}_{2}$ and $\mathrm{ZnO}$ quantum points was investigated and the efficiency was determined. Although the efficiency of the cell was reported to be about $5 \%$ in a solar cell made of 2:1 ratio $\mathrm{TiO}_{2} @ \mathrm{ZnO}$ composite, the efficiency can be increased by optimizing the conditions or by composing with other materials. In order to increase the efficiency, it is possible to optimize the construction conditions of the perovskite solar cell (in terms of layering, layer thickness, rotational layering time, etc.); Improving the stability of $\mathrm{ZnO}$ quantum dots by composing $\mathrm{TiO}_{2} @ \mathrm{ZnO}$ composites with other materials (such as PbS and materials that affect the efficiency of the solar cell) are other ways to increase efficiency. Also, the use of $\mathrm{TiO}_{2} @ \mathrm{ZnO}$ composite in core-shell composites, the use of $\mathrm{TiO}_{2} @ \mathrm{ZnO}$ composite in multiple (tandem solar cells), and finally locating and optimizing the establishment of solar cell fields are other ways to increase efficiency. 


\section{Declarations}

\section{Conflicts of interest}

The authors declare no conflict of interest.

\section{Data availability}

All data generated or analysed during this study are included in this published article.

\section{References}

1. Ajayan, P., Schadler, L., Braun, P., 2003. Nanocomposite Science and Technology. A journal by science. DOI:10.1002/3527602127. https://onlinelibrary.wiley.com/doi/book/10.1002/3527602127.

2. Augustine, M.S., Jeeju, P.P., Sreevalsa, V.G., Jayalekshmi, S., 2012. Excellent UV absorption in spincoated thin films of oleic acid modified zinc oxide nanorods embedded in Polyvinyl alcohol. Journal of Physics and Chemistry of Solids. 73,369-401. https://doi.org/10.1016/j.jpcs.2011.11.004

3. Baikie, T., Fang, Y., Kadro, J., Schreyer, M., Wei, F., Mhaisalkar, S., Graetzeld, M., White, T., 2013. Synthesis and crystal chemistry of the hybrid perovskite $(\mathrm{CH} 3 \mathrm{NH} 3) \mathrm{Pbl} 3$ for solid-state sensitised solar cell applications. Journal of Materials Chemistry A. 1, 5628-5641. https://doi.org/10.1039/C3TA10518K.

4. Barrows, A. T., Pearson, A. J., Kyu Kwak, Ch., Dunbar, A. D. F., Buckleya, A. R., Lidzey, D. G., 2014. Efficient planar heterojunction mixed-halide perovskite solar cells deposited via spray-deposition. Energy \& Environmental Science. Issue 9, 2944-2950. https://pubs.rsc.org/en/content/articlelanding/2014/ee/c4ee01546k\#!divAbstract.

5. Bhooshan Kumar, V., Gouda, L., Porat, Z., Gedanken, A., 2016. Sonochemical synthesis of $\mathrm{CH} 3 \mathrm{NH} 3 \mathrm{Pbl} 3$ perovskite ultrafine nanocrystal sensitizers for solar energy applications. Ultrasonics sonochemistry. 32, 54-59. http://doi.org/10.1016/j.ultsonch.2016.02.012.

6. Chen, L., Tang, F., Wang, Y., Gao, Sh., Cao, W., Cai, J., Chen, L., 2015. Facile preparation of organometallic perovskite films and high-efficiency solar cells using solid-state chemistry. Nano Research, 8, 263-270. https://doi.org/10.1007/s12274-014-0662-1.

7. Chueh, Ch., Liao, Ch., Zuo, F., Williams, S. T., Lianga, P., Jen, A., 2015. The roles of alkyl halide additives in enhancing perovskite solar cell performance. Journal of Materials Chemistry A, 3, 90589062. https://doi.org/10.1039/C4TA05012F.

8. Dar, M. I., Ramos, F., XU, Zh., Liu, B., Ahmad, Sh., Shivashankar, S., Nazeeruddin, M., Grätzel, M., 2014. Photoanode Based on (001)-Oriented Anatase Nanoplatelets for Organic-Inorganic Lead lodide Perovskite Solar Cell. Chemistry of Materials, 26, 4675-4678. https://doi.org/10.1021/cm502185s.

9. Das, R., Ambardekar, V., Bandyopadhyay P.P., 2021. Titanium Dioxide and Its Applications in Mechanical, Electrical, Optical, and Biomedical Fields. IntechOpen Book Series. DOI: 10.5772/intechopen.98805. https://www.intechopen.com/chapters/78113 
10. Docampo, P., Hanusch, F., Stranks, S., Doblinger, M., Feckl, J., Ehrensperger, M., Minar, N., Johnston, N., Snaith, H., Bein, TH., 2014. Solution Deposition-Conversion for Planar Heterojunction Mixed Halide Perovskite Solar Cells. Advanced Energy Materials, 4, 1400355.

https://doi.org/10.1002/aenm.201400355.

11. Geng, Sh., Min Lin, Sh., Bing Li, N., Qun Luo, H., 2017. Polyethylene glycol capped ZnO quantum dots as a fluorescent probe for determining copper(II) ion. Sensors and Actuators B: Chemical. 253, 137143. https://doi.org/10.1016/j.snb.2017.06.118.

12. Hasti, F. Pezhooli, N., Maleki, A., Rouhi, H., SalmanMahiny, A., Sakieh, Y., Shalan, A. E., 2022. Site selection analysis of solar cell farms based on GIS and spatial planning approaches in Kurdistan province, western Iran. (under review).

13. Hwang, K., Junholes, Y., Watkins, S., Subbiah, J., Jones, D., Kim, D., Vak, D., 2015. Toward Large Scale Roll-to-Roll Production of Fully Printed Perovskite Solar Cells. Advanced materials. Volume 27, Issue 7, 1241- 1247. https://onlinelibrary.wiley.com/doi/abs/10.1002/adma.201404598.

14. Im, J.H., Lee, Ch., Lee, J.W., Park, S.W., Park, N.G., 2011. 6.5\% efficient perovskite quantum-dotsensitized solar cell. Nanoscale. 3, 4088-4093. https://doi.org/10.1039/C1NR10867K

15. Jasim, Kh., 2015. Quantum Dots Solar Cells. Intechopen Book Series. DOI: 10.5772/59159. https://www.intechopen.com/chapters/47671

16. Kaur, A., Umar, A., Kumar Kansal, S., 2015. Sunlight-driven photocatalytic degradation of nonsteroidal anti-inflammatory drug based on TiO2 quantum dots. Journal of colloid and interface science. 459, 257-263. https://doi.org/10.1016/j.jcis.2015.08.010.

17. Khan, I., Khan, A., Khan, M, A., Khan, S., Verpoort, F., Umar, A., 2020. Hybrid Perovskite Composite Materials, Design to Applications. Woodhead Publishing. https://www.elsevier.com/books/hybridperovskite-composite-materials/khan/978-0-12-819977-0.

18. Lee, M. M., Teuscher, T., Miyasaka, T., Murakami, T. N., Snaith, H.J., 2012. Efficient hybrid solar cells based on meso-superstructured organometal halide perovskites. Sci. 338, 643-647. https://science.sciencemag.org/content/338/6107/643/tab-pdf.

19. Liang, P., Chueh, CH., Xin, X., Zou, F., Williams, S., Liao, Ch., Jen, A., 2015. High-Performance PlanarHeterojunction Solar Cells Based on Ternary Halide Large-Band-Gap Perovskites. Advanced Energy Materials. Volume 5, Issue 1, 1400960.

https://onlinelibrary.wiley.com/doi/abs/10.1002/aenm.201400960.

20. Luo, J., Daniel, I., 2003. Characterization and modeling of mechanical behavior of polymer/clay nanocomposites. Composites science and technology. 63, 1607-1616.

https://doi.org/10.1016/S0266-3538(03)00060-5.

21. Malinkiewicz, O., Carmona, C., Soriano, A., Bandiello, E., Camacho, L., Nazeeruddin, M., Bolink, H., 2014. Metal-Oxide-Free Methylammonium Lead lodide Perovskite-Based Solar Cells: the Influence of Organic Charge Transport Layers. Advanced Energy Materials, 4, 14003455. https://doi.org/10.1002/aenm.201400345. 
22. McDonald, C., Ni, Ch., Maguire, P., Connor, P., Irvine, J. T. S., Mariotti, D., Svrcek, V., 2019. Nanostructured Perovskite Solar Cells. Nanomaterials. 9, 1481. https://doi.org/10.3390/nano9101481.

23. Noh, J.H., Jeon, N.J., Choi, Y.Ch., Nazeeruddin, M.K., Gratzel, M., Seok, S., 2013. Nanostructured $\mathrm{TiO}_{2} / \mathrm{CH}_{3} \mathrm{NH}_{3} \mathrm{Pbl}_{3}$ heterojunction solar cells employing spiro-OMeTAD/Co-complex as holetransporting material. Journal of Materials Chemistry A. 1, 11842-11847. https://doi.org/10.1039/C3TA12681A

24. Prakash Singh, S., Nagarjuna, P., 2014. Organometal halide perovskites as useful materials in sensitized solar cells. Nagarjuna. Dalton Transactions. 43, 5247-5251. https://doi.org/10.1039/C3DT53503G.

25. Pourradi, H., Ghani, K., Mahdavi, M., 2019. Nano Structured Zn-Al Layered Double Hydroxide Synthesis and Its Effect on the Perovskite Solar Cell Efficiency. Journal of color and technology. Volume 12. Page 261-269. http://jcst.icrc.ac.ir/article_77177.html?lang=en.

26. Shalan, A. E., Akman, E., Sadegh, F., Akin, S., 2021. Efficient and Stable Perovskite Solar Cells Enabled by Dicarboxylic Acid-Supported Perovskite Crystallization. The Journal of Physical Chemistry Letters. 12, 3, 997- 1004. https://doi.org/10.1021/acs.jpclett.0c03566.

27. Shalan, A. E., Mohammed, M. K. A., Govindan, N., 2021. Graphene assisted crystallization and charge extraction for efficient and stable perovskite solar cells free of a hole-transport layer. RSC Advances. 11, 4417. https://doi.org/10.1039/D0RA09225H.

28. Sood, S., Mehta, S.K., Umar, A., Kansal, S.K., 2014. The visible light-driven photocatalytic degradation of Alizarin red S using Bi-doped $\mathrm{TiO}_{2}$ nanoparticles. New Journal of Chemistry. 38, 3127-3136. https://doi.org/10.1039/C4NJ00179F

29. Stranks, S., Eperon, G., Grancini, G., Meneloau, Ch., Alcocer, M., Leijtens, T., Herz, L., Petrozza, A., Snaith, H., 2013. Electron-Hole Diffusion Lengths Exceeding 1 Micrometer in an Organometal Trihalide Perovskite Absorber. Science. 342, 341-344. DOI: 10.1126/science.1243982

30. Sun, D., Sue, H.J., Miyatake, N., 2008. Optical Properties of ZnO Quantum Dots in Epoxy with Controlled Dispersion. The Journal of Physical Chemistry C. 112, 16002-16010. https://doi.org/10.1021/jp805104h

31. Sun, H., Dai, P., Li, X., Ning, J., Wang, Sh., Qi, Y., 2021. Strategies and methods for fabricating high quality metal halide perovskite thin films for solar cells. Journal of Energy Chemistry. 60, 300-333. https://doi.org/10.1016/j.jechem.2021.01.001

32. Sun, H., Ruan, P., Bao, Zh., Chen, L., Zhou, X., 2015. Shell-in-Shell TiO2 hollow microspheres and optimized application in light-trapping perovskite solar cells. Solid State Sciences, 40, 60-66. https://doi.org/10.1016/j.solidstatesciences.2014.12.015

33. Theng, B., 2012. Formation and Properties of Clay-Polymer Complexes. Elsevier, Amesterdam. https://www.worldcat.org/title/formation-and-properties-of-clay-polymer complexes/oclc/1058914201. 
34. Tong, Y.H., Liu, Y.C., Lu, S.X., Dong, L., Chen, S.J., Xiao, Z.Y., 2004. The Optical Properties of ZnO Nanoparticles Capped with Polyvinyl Butyral. Journal of Sol-Gel Science and Technology volume. 30, 157-161. https://doi.org/10.1023/B:JSST.0000039500.48283.5a

35. Xing, G., Mathews, N., Sun, Sh., Lim, S., Lam, Y., Gratzel, M., Mhaisalkar, S., Sum, T., 2013. Long-Range Balanced Electron- and Hole-Transport Lengths in Organic-Inorganic $\mathrm{CH}_{3} \mathrm{NH}_{3} \mathrm{Pbl}_{3}$. Science. 342, 344347. DOI: $10.1126 /$ science. 1243167

36. Yang, W., Zhang, B., Ding, N., Ding, W., Wang, L., Yu, M., Zhang, Q., 2016. Fast synthesize ZnO quantum dots via ultrasonic method. Ultrasonics Sonochemistry. 30, 103-112. http://dx.doi.org/10.1016/j.ultsonch.2015.11.015

\section{Figures}

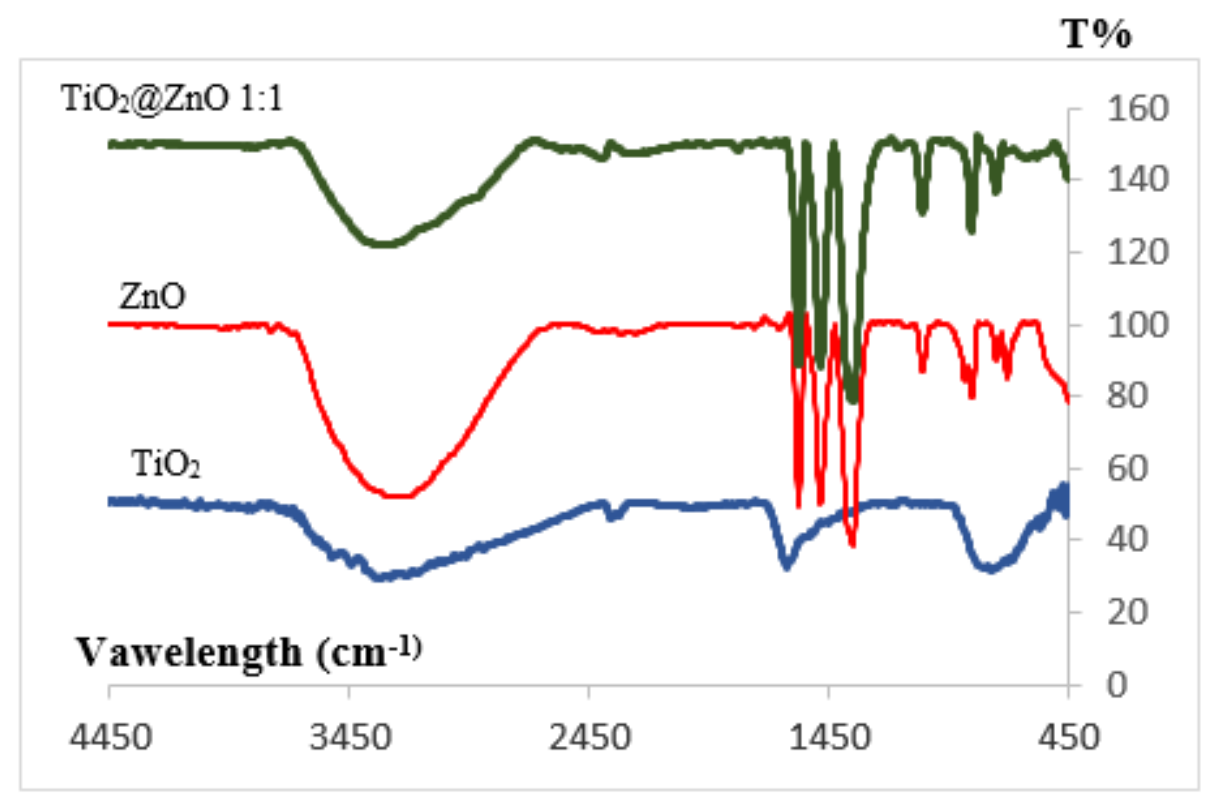

Figure 1

FT-IR spectra of $\mathrm{ZnO}$ and $\mathrm{TiO}_{2}$ quantum dots and their composites 

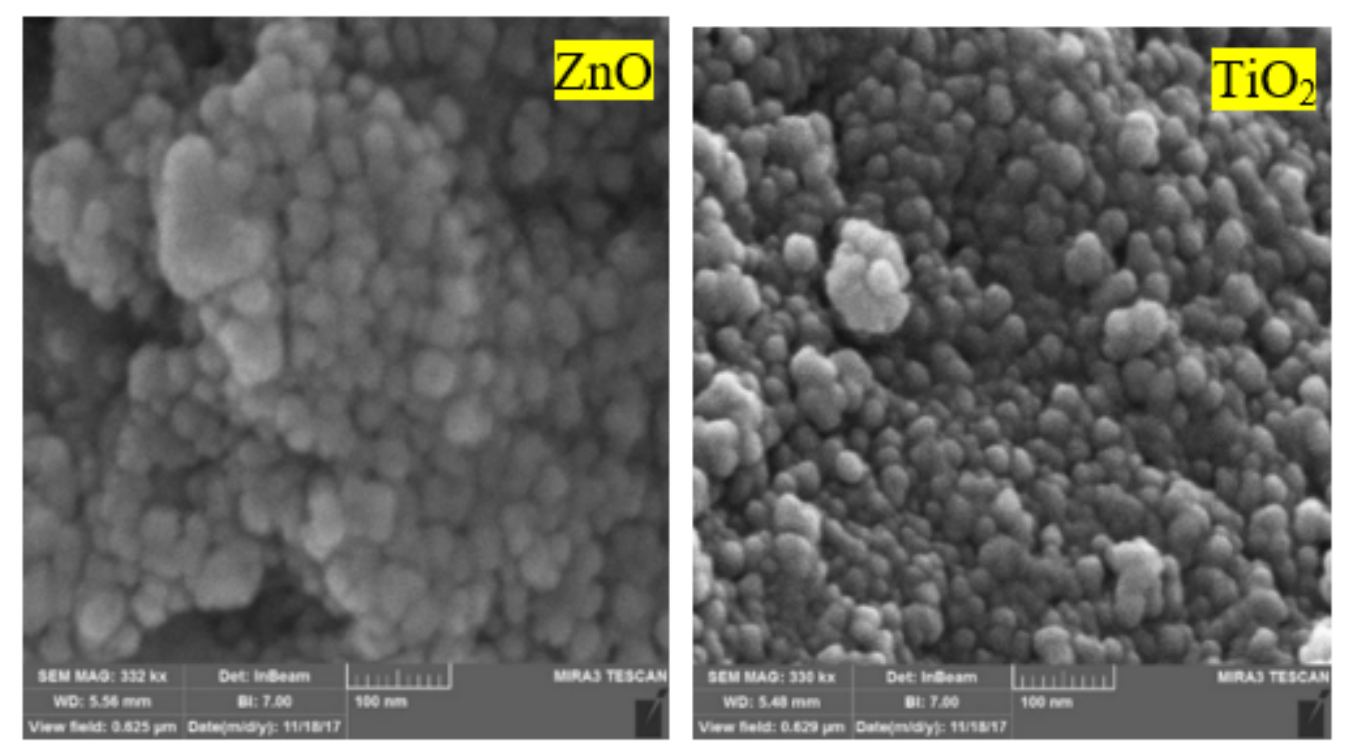

\section{Figure 2}

FE-SEM of $\mathrm{TiO}_{2}$ quantum dots and $\mathrm{ZnO}$ quantum dots
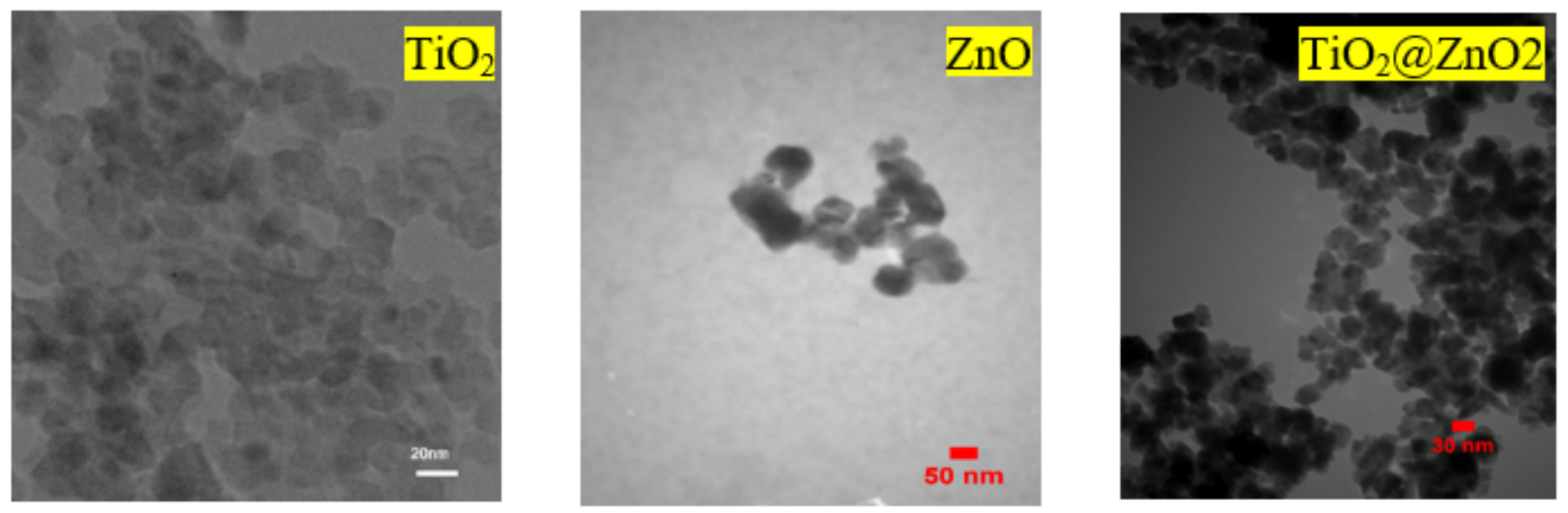

Figure 3

TEM of $\mathrm{TiO}_{2}$ quantum dots, $\mathrm{ZnO}$ quantum dots and $\mathrm{TiO}_{2} @ \mathrm{ZnO}$ composite 


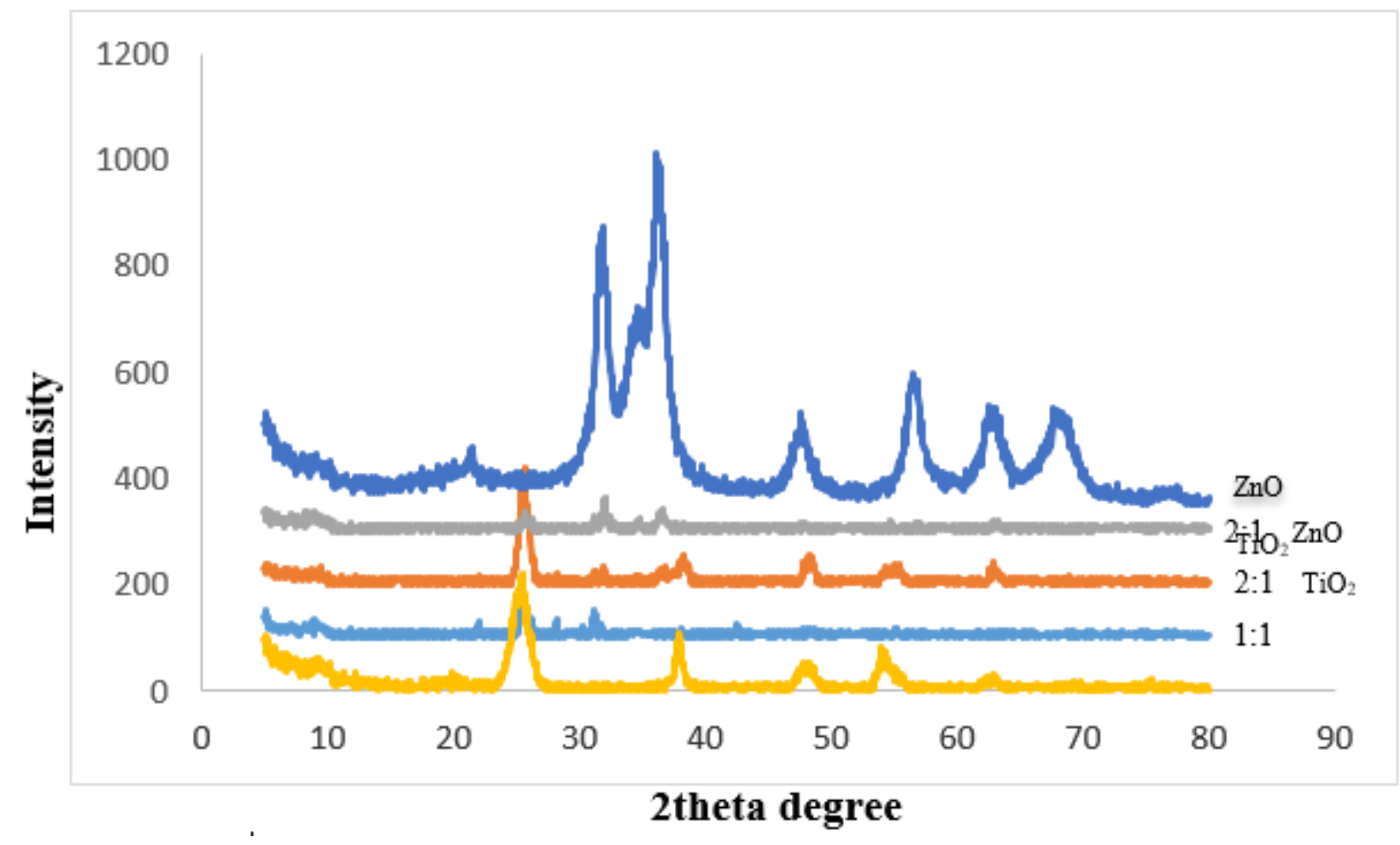

Figure 4

XRD pattern of $\mathrm{TiO}_{2}$ quantum dots, $\mathrm{ZnO}$ quantum dots and $\mathrm{TiO}_{2} @ \mathrm{ZnO}$ composite 

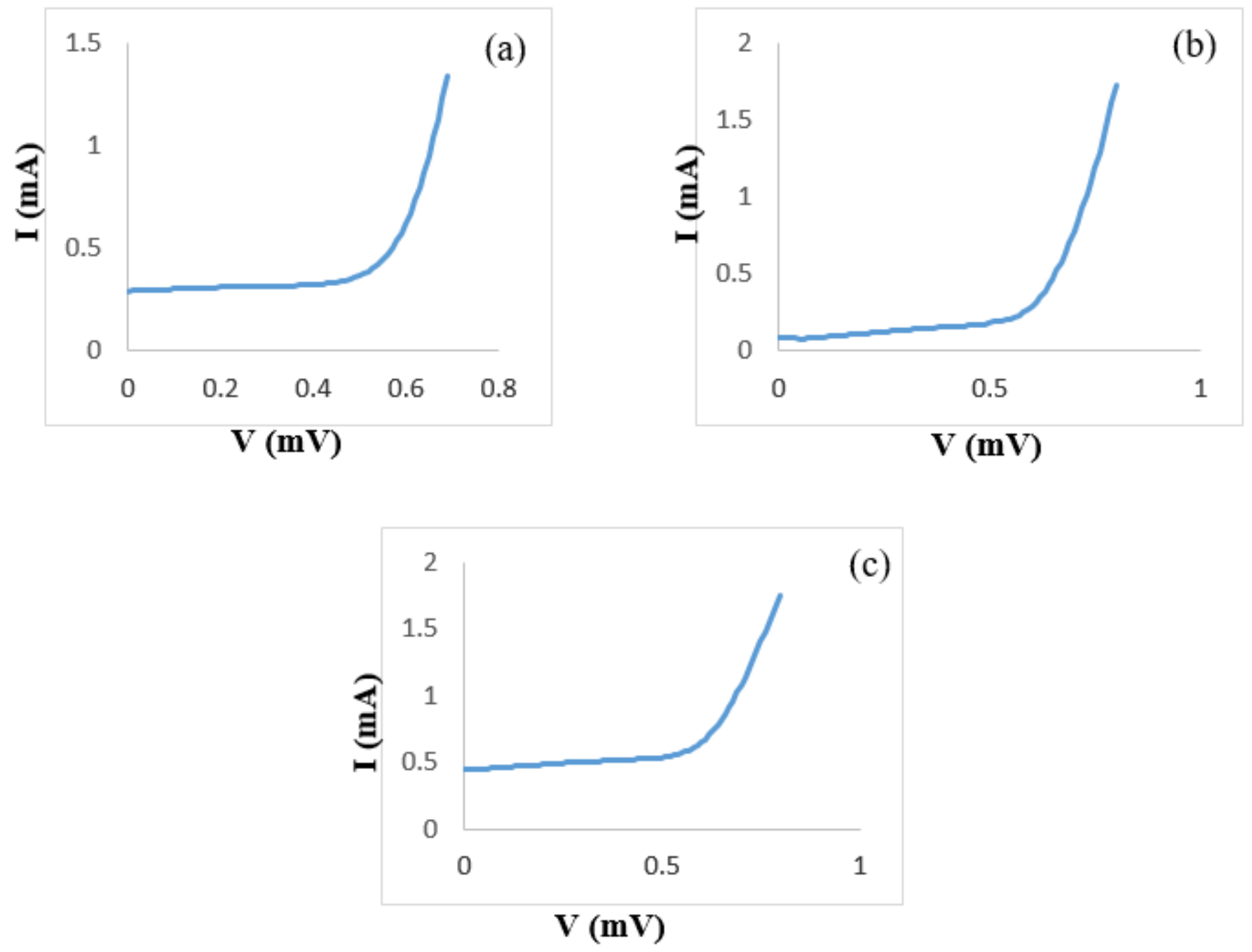

Figure 5

I-V graph a)1:1 $\mathrm{TiO}_{2} @ \mathrm{ZnO}$, b) 2: 1 ratio of $\mathrm{TiO}_{2} @ \mathrm{ZnO}, \mathrm{c}$ )2:1 ratio $\mathrm{ZnO} @ \mathrm{TiO}_{2}$ composite 